\title{
CHARACTERISATION AND GRADING OF THREE SELECTED TIMBER SPECIES GROWN IN KWARA STATE NIGERIA ACCORDING TO EN 338 (2009) FOR STRUCTURAL USE
}

\author{
A. A. Jimoh ${ }^{1}$ and B. J. Ibitolu ${ }^{2, *}$

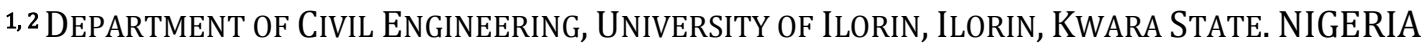 \\ E-mail addresses:1aajimoh4real@yahoo.com, 2ibitunlex01@gmail.com
}

\begin{abstract}
This paper is aimed at classifying three potential timbers grown in Nigeria using EN338 (2009) strength classification for structural size specimen. The timbers namely Vitex doniana, Ceiba pentandra and Pseudocedrela kotschyi were obtained in Ilorin, Kwara State of Nigeria. Physical and Mechanical properties of the selected timber species were determined in accordance with EN 13183-1 (2002) and EN 408 (2003) for structural timbers. Four point bending tests based on EN 408 (2003) with specimen $50 \times 50 \times 1000 \mathrm{~mm}$ were carried out using a Universal Testing Machine (UTM) to determine the bending strength and Modulus of Elasticity of the each timber specie. Characterisitc values of Bending strength, Modulus of Rupture and Density were determined using EN 384(2004). The timber species; Vitex doniana, Ceiba pentandra and Pseudocedrela kotschyi had equilibrium moisture content (EMC) of 15.70\%, $13.71 \%$ and $24.28 \%$ respectively. Strength grading of timber species was then conducted by adjusting the material properties values of species to $12 \%$ moisture content using the required adjustment factors. The timber were then graded according to EN338 (2009). Pseudocedrela kotschyi had the highest density of $813 \mathrm{~kg} / \mathrm{m}^{3}$ followed by Vitex doniana $\left(706 \mathrm{~kg} / \mathrm{m}^{3}\right)$ while Ceiba pentandra had the lowest density of $402 \mathrm{~kg} / \mathrm{m}^{3}$. Vitex doniana, ceiba pentandra and Pseudocedrela kotschyi were assigned to strength class D30,C16 and D35 respectively in accordance with EN338(2004).
\end{abstract}

Keywords: Bending strength, classification, density, modulus of elasticity, Nigerian grown timber structural use

\section{INTRODUCTION}

Global demand for timber is increasing annually at the rate of 1.7 per cent. At the same time, forestry resources are not adequate to meet current demands. The scope for enlargement of forested areas is limited. This trend creates pressure on the economy that encourages the commercial exploitation of natural forests unless supply can be increased through the establishment of high yielding plantations [1]. Timber was found to be the world most successful fibre composite because of its low density, cellular and polymeric composite which overlaps into numerous classes of materials. Careful exploration of its structural properties has shown that it is adequate for designing an environmentally friendly structure which is cost effective [2]. Selecting timber is not easy as it seems because timber has various types and selecting the right material for the right use is key. There are many useful needs of timber during the construction of building such as doors, ceilings, railings and windows and all these contribute a lot in the beautification and overall look of interiors. Timber has many other uses but which type of timber should be used for right purpose is important to know because if timber used in construction comes out to be of low quality then one may need replacement again and again [3]. Before purchasing timber material for construction, adequate information regarding timber types and forms must be known because to select a single knot can bring down the show of a whole woodwork. Trees grow best in temperate and moist tropical climates but do not grow in cold or very dry areas of Nigeria. Furthermore, Nigeria as a nation is now allocating huge resources on importation of steel which is not necessary even in fabrication of long span trusses for sophisticated structures because timber can be used to achieve strength, durability, aesthetic and even time conservation [4].

Structural timber is the timber used in framing and load-bearing structures, where strength is the major

* Corresponding author tel: +234-806-010 - 8550 
factor in its selection and use. Most woods used in the building construction are softwoods but in structures like bridges and railway sleepers, hardwoods are specially used [5]. For structural usage, the properties of large size specimens are preferred to those of small clear specimens because of unavoidable defects such as shakes, knots other defects found in wood [6]. Classification of these timbers to standards then becomes of great importance because of diverse and also similar properties of some of them. When a timber is classified and graded, designers can easily use different available timbers for a purpose.

This paper intends to classify potential Nigerian timbers in accordance with EN338 [7] which is the limit state design. This will give an opportunity to adopt the Euro code 5 design procedure in the Nigerian case of study which is the permissible stress design. The objective of the study is as follows:

1 To characterize selected timber species for their physical and mechanical properties according to EN 408 and adjustment of characteristic values with respect to moisture content at $12 \%$.

2 To classify selected Timber species to strength grades according to EN 338.

\section{MATERIALS AND METHODS}

\subsection{Materials}

The materials used in this paper are timber logs obtained from Kwara State in North-Central part of Nigeria. Timber logs sawn into $(100 \mathrm{~mm} \times 150 \mathrm{~mm} x$ $3000 \mathrm{~mm}$ ) were purchased from the sawmills to be used for the project and this were conditioned at the standard environment of $(20 \pm 2){ }^{\circ} \mathrm{C}$ and $(65 \pm 5) \%$ relative humidity according to EN 408(2003). Plate 1 shows the timbers sampled from the sawmills. Each piece of logs were weighed successively at intervals of 24 hours and recorded until a relative constant mass is attained. This timber species are Vitex doniana, Ceiba pentandra and Pseudocedrela kotschyi as shown in Table 1.

\subsection{Preparation of Test Specimen}

For bending strength and Modulus of Elasticity (MOE) tests, 120 No. beams of $50 \mathrm{~mm} \times 50 \mathrm{~mm} \times 1000 \mathrm{~mm}$ each, that is, 40 pieces per specie, were prepared with the aid of sawing and milling machines at the wood processing unit of the Department of Civil Engineering, University of Ilorin, Ilorin, Nigeria. For moisture content and density tests, a total of 20 test specimens each of size $50 \mathrm{~mm} \times 50 \mathrm{~mm} \times 50 \mathrm{~mm}$ sawn after bending tests from timber beams section close to fracture were also prepared at the same unit.

\subsection{Moisture content of Timber}

The timber species moisture contents (MCs) were determined in accordance with EN 13183-1 [8] and EN 408 [9]. The MC for each timber was obtained by first measuring its initial mass before drying using an electronic weighing balance. The test sample were then oven dried at a temperature of $103 \pm 2^{0} \mathrm{c}$. The specimens were dried until the final weight of ovendried timber is constant after two successive weighing. The initial and oven dry mass of each specimen sample were recorded and the MC was then computed from Equation (1):

$$
M C=\frac{m_{1}-m_{2}}{m_{2}} \times 100 \%
$$

where $m_{1}$ and $m_{2}$ and $M C$ are the initial mass, oven dry mass and MC of test specimen respectively. The mean moisture content was then obtained by finding the mean value of MC for the 15 specimens of each timber specie.

\subsection{Density}

The density of timber is its mass per unit volume at a specified value of MC. The density of specimen was determined in accordance with EN 408 [9] using Equation (2) with its characteristic values determined in accordance with EN 384 [10] from Equation (3).

$$
\begin{gathered}
\text { Density, } \quad \rho=\frac{\text { Mass }}{\text { Volume }} \mathrm{g} / \mathrm{cm}^{3} \\
P_{k}=P_{05}=P-1.65 \mathrm{~s}
\end{gathered}
$$

where $P_{k}$ is the characteristic density, $P_{05}$ is the 5percentile density, $\mathrm{P}$ and $s$ are the mean and the standard deviation of densities of all specimen (in $\mathrm{kg} / \mathrm{m}^{3}$ ), respectively.

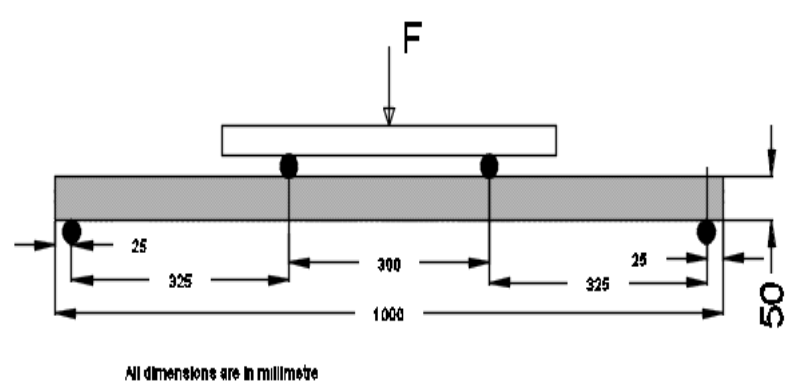

Figure 1: Bending test setup and specimen dimension

Table 1: Timber Nomenclature

\begin{tabular}{lllll}
\hline Botanical Names & Family Name & Local Name & Where grown & Colour \\
\hline Vitex doniana & Lamiaceae & Eriri & Kwara Kogi (common) & Yellowish \\
Ceiba pentandra & Malvaceae & Somi & Ekiti (Otun) Aparo Ekiti & Blackish yellow \\
Pseudocedrela kotschyi & Maliaceae & Emi- gbegi & Kwara Kogi & Reddish brown \\
\hline
\end{tabular}




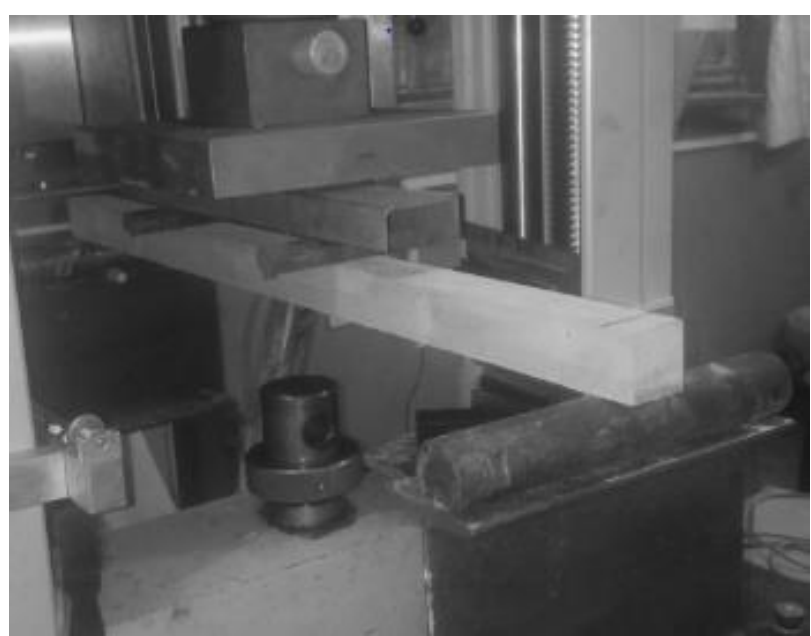

Figure 2: Four Point Bending test Setup

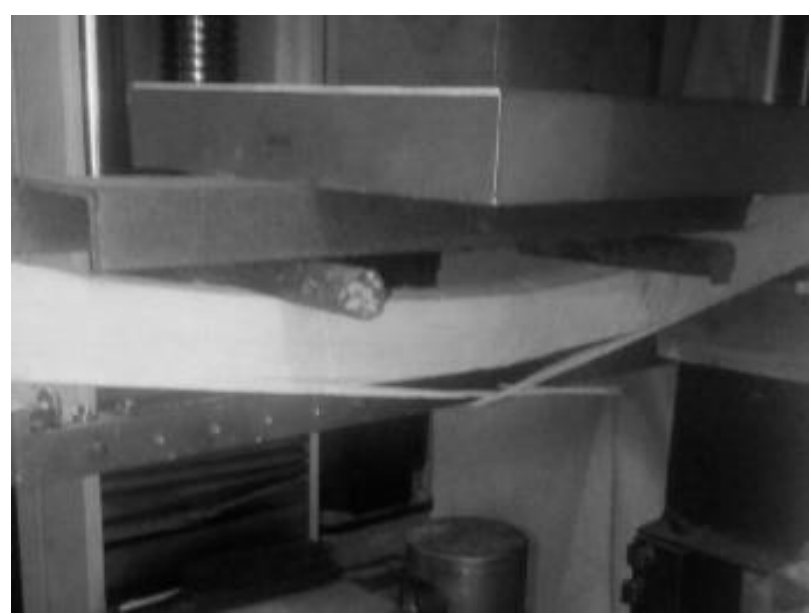

Figure 3: Failure Mode of 4-point Bending Test

\subsection{Bending Strength}

This was carried out in accordance with EN 408 [9] for structural timber. The strength tests were carried out with the aid of a Universal Testing Machine (UTM) with a maximum load capacity of $300 \mathrm{KN}$ at the Agricultural
Engineering Laboratory of the University of Ilorin. The UTM has a square shaped loading head. The Modulus of Rupture was computed from Equation (4).

$$
f_{m}=\frac{a F_{\max }}{2 W}
$$

where $\mathrm{a}$ is the distance between loading position and the nearest support ( $\mathrm{mm}$ ), $\mathrm{F}_{\max }$ is the maximum load $(\mathrm{N}), \mathrm{W}$ is the section modulus $\left(\mathrm{mm}^{3}\right)$ and $\mathrm{f}_{\mathrm{m}}$ is the bending strength $\left(\mathrm{N} / \mathrm{mm}^{2}\right)$.

According to [10], the characteristic values of strength properties based on the measured MC were computed from Equation (5) derived from EN 384 [11]:

$$
f_{k}=1.12 f_{05}
$$

where $f_{k}$ and $f_{05}$ are the characteristic and 5thpercentile values of bending strength, respectively. Figure 1, Figure 2 and Figure 3 show the specimen dimension, bending strength setup and its failure mode, respectively.

\subsection{Modulus of Elasticity}

The Local modulus of Elasticity was derived from the four point bending test as prescribed in EN408 [9]. The rate of movement of the loading head was adjusted not to be greater than $9 \mathrm{~mm} / \mathrm{min}$. The guage length for the test is five (5) times the depth of the section $(250 \mathrm{~mm})$. The local modulus of elasticity was then computed using the following expression:

$$
E_{m, l}=\frac{\mathrm{a} l_{1}^{2}\left(F_{2}-F_{1}\right)}{16 \mathrm{I}\left(w_{2}-w_{1}\right)}
$$

where $E_{m, l}$ is the local MOE in bending, a is the distance between inner point loads and supports $(\mathrm{mm}), \mathrm{l}_{1}$ is the gauge length $(250 \mathrm{~mm}),\left(F_{2}-F_{1}\right)$ is the increment load (in Newton) on the regression line with a correlation coefficient of 0.99 and $\left(\mathrm{w}_{2}-\mathrm{w}_{1}\right)$ is the increment of deformation $(\mathrm{mm})$ corresponding to $\left(\mathrm{F}_{2}-\mathrm{F}_{1}\right)$.

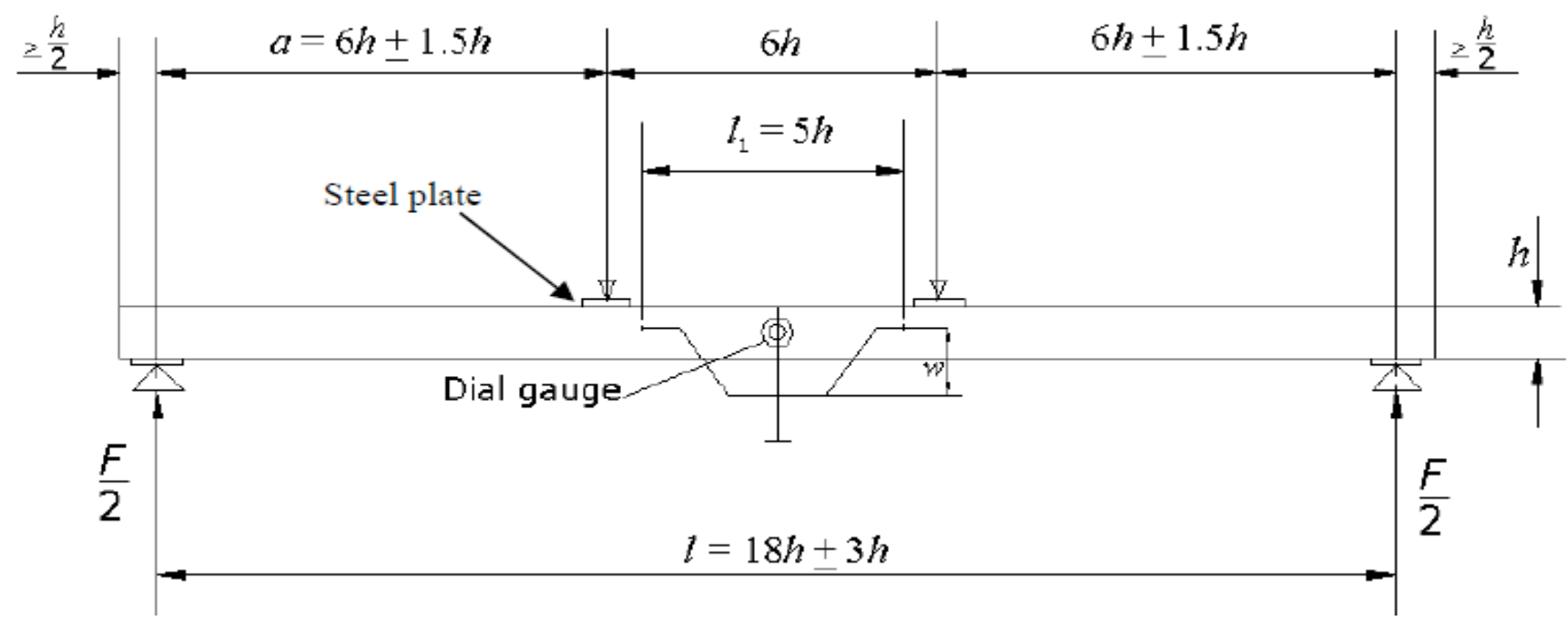

Figure 4: Setup for measuring local modulus of Elasticity in Bending [6] 
Characteristic values of MOE, which is also the mean modulus of elasticity based on measured moisture content is then calculated from the equation as given in EN 384:2004

$$
\text { Emean }=\left(\frac{\sum E_{i}}{n}\right) \quad 1.3-2690
$$

where $E_{i}$ is the ith value of MOE, $n$ is the number of specimens and $E_{\text {mean }}$ is the mean value of MOE in bending. A sketch for determining the Local MOE in bending is shown in Figure 4.

\subsection{Adjusting Values To $12 \%$ Moisture Content Equivalent}

Mechanical strength properties are affected by variation in moisture content below the fibre saturated point. Generally, many of the strength properties increase as wood is dried. Above the fibre saturation point (FSP), most of the mechanical properties are not affected by changes in moisture content [12]. Strength class values according to EN 338 [7] for structural timbers are derived from timbers at about 12\% moisture content, which is taken as a reference moisture content.

Thus the strength characteristics of timber were adjusted to $12 \%$ reference moisture content using Equation (8).

$$
F_{12}=F_{w}(1+\alpha(W-12)
$$

Where: $F_{12}$ is the ultimate strength at $12 \%$ moisture content, $\mathrm{W}$ is the moisture content at the time of testing, $F_{w}$ is the ultimate strength at the moisture content at the time of testing, $\alpha$ is the adjustment factor for moisture content, equivalent to the percentage change in strength values for $1 \%$ change in moisture content. This is contained in Table 1

\section{Table 1: Adjustment factor for Wood state of stress}

\begin{tabular}{lll}
\hline State of stress & $\begin{array}{l}\alpha \text { (for all wood } \\
\text { specie) }\end{array}$ & Reference \\
\hline Modulus of Elasticity ( & 0.02 & {$[11]$} \\
$\left.\mathrm{E}_{\mathrm{m}}, \mathrm{E}_{\mathrm{c}, 0}\right)$ & & {$[13]$} \\
Bending Strength & 0.04 & {$[14]$} \\
Density & -0.005 & \\
\hline
\end{tabular}

\subsection{Other Mechanical Properties}

Characteristic values of other mechanical properties at $12 \%$ MC such as tensile strengths parallel and perpendicular to grain, shear modulus, compressive strength parallel and perpendicular to grain and other stiffness properties of the timbers were determined using the following equations from Annex $\mathrm{A}$ of EN338(2009).
The characteristic values of tensile strength parallel to grain $\left(f_{\mathrm{t}, 0, \mathrm{k}}\right)$ and compressive strength parallel to grain( $\left.f_{\mathrm{c}, 0, \mathrm{k}}\right)$ are computed from the Equations (9) and (10), respectively:

$$
\begin{gathered}
f_{\mathrm{t}, 0, \mathrm{k}}=0.6 f_{\mathrm{m}, \mathrm{k}} \\
f_{\mathrm{c}, 0, \mathrm{k}}=5\left(f_{m, \mathrm{k}}\right)^{0.45}
\end{gathered}
$$

The characteristic values of tensile strength perpendicular to grain $\left(f_{\mathrm{t}, 90, \mathrm{k}}\right)$ and compressive strength perpendicular to grain $\left(f_{\mathrm{c}, 90, \mathrm{k}}\right)$ are computed from Equations (11)-(14):

$$
\begin{array}{cl}
f_{\mathrm{t}, 90, \mathrm{k}}=0.4 \mathrm{~N} / \mathrm{mm}^{2} & \text { for softwoods } \\
f_{\mathrm{t}, 90, \mathrm{k}}=0.6 \mathrm{~N} / \mathrm{mm}^{2} & \text { for hardwoods } \\
f_{\mathrm{c}, 90, \mathrm{k}}=0.007 \rho \mathrm{k} & \text { for softwoods } \\
f_{\mathrm{c}, 90, \mathrm{k}}=0.015 \rho \mathrm{k} & \text { for hardwoods }
\end{array}
$$

Fractile $5^{\text {th }}$ percentile values of MOE parallel to grain $\left(E_{0,0.05}\right)$ was computed from Equations (15) and (16):

$$
\begin{array}{cc}
E_{0,0.05}=0.67 E_{0, \text { mean }} & \text { for softwoods } \\
E_{0,0.05}=0.84 E_{0, \text { mean }} & \text { for hardwoods }
\end{array}
$$

The characteristic values of mean modulus of elasticity perpendicular to grain ( $\left.E_{90 \text {,mean }}\right)$ for the timbers were computed from the Equations (17) and (18):

$$
\begin{gathered}
E_{90, \text { mean }}=E_{0, \text { mean }} / 30 \quad \text { for softwoods } \\
E_{90, \text { mean }}=E_{0, \text { mean }} / 15 \quad \text { for hardwoods }
\end{gathered}
$$

The characteristic values of mean shear modulus $\left(G_{\text {mean }}\right)$ were computed from Equation (19):

$$
G_{\text {mean }}=E_{0, \text { mean }} / 16
$$

The characteristic mean density $\left(\rho_{\text {mean }}\right)$ is computed from Equation (20):

$$
\rho_{\text {mean }}=1.2 \times \rho_{k}
$$

Shear strength $\mathrm{f}_{\mathrm{t}, 0, \mathrm{k}}$, was taken from Table 1 of EN 338 (2009) as specified by the code.

In Equations (9) to (20), $E_{0, \text { mean }}$ is the mean MOE parallel to grain, $\rho_{k}$ is the characteristic density while $f$ $\mathrm{m}, \mathrm{k}$ is the characteristic bending strength all which are used to derive the other mechanical properties. Shear strength $f_{\mathrm{v}, \mathrm{k}}$ would be taken from Table 1 of EN338 as put forward by the code. Equations (12)-(19), which differentiate softwood from hardwood, would be dependent on the characteristic density range of the timber in accordance with EN338.

\section{RESULTS AND DISCUSSION}

\subsection{Physical Properties of Timbers}

Table 2 shows the results for the MC of the three (3) timber species. Pseudocedrela kotschyi had the highest equilibrium moisture content (EMC) of $24.28 \%$ followed by Vitex doniana (15.70 \%) and lastly Ceiba pentandra with a MC of $13.71 \%$. Moisture content values in general of the two species were below fiber saturation point (FSP) which is usually between 25-30 $\%$ as recorded in [15]. Table 3 presents the adjusted 12 
$\%$ characteristic density of the timbers to be used for timber classification in accordance with EN338.

\subsection{Mechanical Properties of Timbers}

According to EN 384, characteristic values are values that represent a fractile of the statistical distribution of timber properties. The Characteristic values of mechanical properties and density for structural timber are used for assigning grades and species to the strength classes of EN 338 at 12\% moisture content. This is achieved with only three characteristic values of bending strength, mean modulus of elasticity parallel to grain and density.

Adjusted Characteristic Density, MOE and Bending strength values of Material Properties for the timbers at $12 \% \mathrm{MC}$ is given in Table 4. Vitex doniana (12.134 $\left.\mathrm{kN} / \mathrm{mm}^{2}\right)$, Pseudocedrela kotschyi $\left(12.185 \mathrm{kN} / \mathrm{mm}^{2}\right.$ ) and Ceiba pentandra $\left(8.854 \mathrm{kN} / \mathrm{mm}^{2}\right)$ had higher MOE when compared with Macrocarpa bequaertii (8.169 $\mathrm{kN} / \mathrm{mm}^{2}$ ) in [14] but they all fell below White Afara $\left(13.32 \mathrm{kN} / \mathrm{mm}^{2}\right)$ in [16].

Moreso, the bending strength of all timber species considered in this paper as shown in Table 4 were lower than Nauclea diderrichii $\left(54.45 \mathrm{~N} / \mathrm{mm}^{2}\right)$ in [14]. Pseudocedrela kotschyi $\left(39.415 \mathrm{kN} / \mathrm{mm}^{2}\right)$ is similar to Ahun $\left(39.36 \mathrm{~N} / \mathrm{mm}^{2}\right)$ as given in [17]. Table 5 presents the results of the other derived mechanical properties of the Nigerian timber species as computed from Equations (10)-(21).

From the results, the Nigerian timbers were allocated a strength class. This assignment was based on EN338 which states that a solid timber may be assigned to a strength class if its characteristic values of bending strength and density are equal to or exceed the values for the strength class given in Table 1 of EN338, and its characteristic mean MOE in bending equals or exceeds $95 \%$ of the value given for that strength class. Based on this, Vitex doniana was assigned to strength class D30 due to its minimum characteristic bending strength of $30.1 \mathrm{~N} / \mathrm{mm}^{2}$, characteristic density of $706 \mathrm{~kg} / \mathrm{m}^{3}$ and minimum mean MOE parallel to grain of 12.13 $\mathrm{KN} / \mathrm{mm}^{2}$. The characteristic bending strength, mean MOE and density of strength class D30 as provided in EN338 are $30 \mathrm{~N} / \mathrm{mm}^{2}, 11 \mathrm{KN} / \mathrm{mm}^{2}$ and $530 \mathrm{~kg} / \mathrm{m}^{3}$ respectively.

Table 2: Summary of Moisture content result

\begin{tabular}{llllll}
\hline Timber specie & $\begin{array}{l}\text { Mean Moisture } \\
\text { content (\%) }\end{array}$ & $\begin{array}{l}\text { Standard } \\
\text { Deviation } \\
(\%)\end{array}$ & $\begin{array}{l}\text { Coefficient of } \\
\text { variation }\end{array}$ & $\begin{array}{l}\text { 95\% Confidence } \\
\text { Interval }\end{array}$ & $\begin{array}{l}99 \% \text { Confidence } \\
\text { Interval }\end{array}$ \\
\hline $\begin{array}{l}\text { Vitex doniana } \\
\text { Ceiba pentandra }\end{array}$ & 15.70 & 1.27 & $8.07 \%$ & $14.91 \leq \mathrm{x} \leq 16.487$ & $14.666 \leq \mathrm{x} \leq 16.734$ \\
$\begin{array}{l}\text { Pseudocedrela } \\
\text { kotschyi }\end{array}$ & 24.28 & 0.90 & $6.54 \%$ & $13.152 \leq \mathrm{x} \leq 14.2678$ & $12.977 \leq \mathrm{x} \leq 14.443$ \\
\hline
\end{tabular}

Table 3: Mean and Characteristic density of Timbers

\begin{tabular}{|c|c|c|c|c|}
\hline Timber Type & $\begin{array}{l}\text { Mean Density } \boldsymbol{\rho} \\
\left(\mathrm{Kg} / \mathrm{m}^{3}\right)\end{array}$ & $\begin{array}{l}\text { Standard } \\
\text { Deviation } \\
\left(\mathrm{Kg} / \mathrm{m}^{3}\right)\end{array}$ & $\begin{array}{l}\text { Characteristic Density } \\
\boldsymbol{\rho}_{\boldsymbol{k}}\left(\mathrm{Kg} / \mathrm{m}^{3}\right)\end{array}$ & $\begin{array}{l}\text { 12\% MC Density } \\
\boldsymbol{\rho}_{\boldsymbol{k}, \mathbf{1 2} \%}\left(\mathrm{Kg} / \mathrm{m}^{3}\right)\end{array}$ \\
\hline Vitex doniana & 834 & 69.356 & 720 & 706 \\
\hline ceiba pentandra & 450 & 27.290 & 405 & 402 \\
\hline $\begin{array}{l}\text { Pseudocedrela } \\
\text { kotschyi }\end{array}$ & 1002 & 82.329 & 866 & 813 \\
\hline
\end{tabular}

Table 4: Adjusted Characteristic values of Material properties to $12 \% \mathrm{MC}$

\begin{tabular}{lccc}
\hline Timber Type & Density $\boldsymbol{\rho}_{\boldsymbol{k}, \mathbf{1 2} \%}\left(\mathrm{Kg} / \mathrm{m}^{3}\right)$ & $\begin{array}{c}\text { Modulus of Elasticity } \\
\mathrm{E}_{0, \text { mean }}\left(\mathrm{N} / \mathrm{mm}^{2}\right)\end{array}$ & $\begin{array}{c}\text { Bending Strength } \\
\mathrm{fm}_{\mathrm{k}} \mathrm{k}_{12} \%\left(\mathrm{~N} / \mathrm{mm}^{2}\right)\end{array}$ \\
\hline Vitex doniana & 706 & 12134.30 & 30.098 \\
ceiba pentandra & 402 & 8853.71 & 21.985 \\
Pseudocedrela kotschyi & 813 & 12185.45 & 39.415 \\
\hline
\end{tabular}


Table 5: Derived Mechanical properties of the Timbers

\begin{tabular}{|c|c|c|c|}
\hline \multirow[b]{2}{*}{ Other Mechanical Properties } & \multicolumn{3}{|c|}{ Timber Specie } \\
\hline & $\begin{array}{l}\text { Eriri Vitex } \\
\text { doniana }\end{array}$ & $\begin{array}{l}\text { Somi Ceiba } \\
\text { pentandra }\end{array}$ & $\begin{array}{c}\text { Emi-Gbegi Pseudocedrela } \\
\text { kotschyi }\end{array}$ \\
\hline $\begin{array}{l}\text { Tension Parallel } \\
\boldsymbol{f}_{\boldsymbol{t}, \mathbf{0}, \boldsymbol{k}}\left(\mathrm{N} / \mathrm{mm}^{2}\right)\end{array}$ & 18.0 & 13.2 & 23.4 \\
\hline $\begin{array}{l}\text { Tension Perpendicular } \\
\boldsymbol{f}_{\left.\boldsymbol{t}, \mathbf{9 0 , \boldsymbol { k }} \boldsymbol{( \mathrm { N }} / \mathrm{mm}^{2}\right)}\end{array}$ & 0.6 & 0.4 & 0.6 \\
\hline $\begin{array}{l}\text { Compression Parallel } \\
\boldsymbol{f}_{\boldsymbol{c}, \mathbf{0}, \boldsymbol{k}}\left(\mathrm{N} / \mathrm{mm}^{2}\right)\end{array}$ & 23.10 & 20.09 & 25.99 \\
\hline $\begin{array}{l}\text { Compression Perpendicular } \\
\boldsymbol{f}_{\boldsymbol{c}, \mathbf{9 0 , \boldsymbol { k }}}\left(\mathrm{N} / \mathrm{mm}^{2}\right)\end{array}$ & 10.6 & 2.8 & 12.2 \\
\hline $\begin{array}{l}\text { Shear Strength } \\
\boldsymbol{f}_{\boldsymbol{v}, \boldsymbol{k}}\left(\mathrm{N} / \mathrm{mm}^{2}\right) \\
5 \% \mathrm{MOE}, \text { Parallel }\end{array}$ & 4.5 & 4.0 & 4.5 \\
\hline $\boldsymbol{E}_{0,0.05}\left(\mathrm{KN} / \mathrm{mm}^{2}\right)$ & 10.20 & 5.93 & 10.23 \\
\hline $\begin{array}{l}\text { Mean MOE, Perpendicular } \\
\boldsymbol{E}_{\mathbf{9 0}, \text { mean }}\left(\mathrm{KN} / \mathrm{mm}^{2}\right)\end{array}$ & 0.809 & 0.295 & 0.812 \\
\hline $\begin{array}{l}\text { Mean Shear Modulus } \\
\boldsymbol{G}_{\text {mean }}\left(\mathrm{KN} / \mathrm{mm}^{2}\right)\end{array}$ & 0.758 & 0.553 & 0.761 \\
\hline $\begin{array}{l}\text { Mean Density } \\
\boldsymbol{\rho}_{\text {mean }}\left(\mathrm{Kg} / \mathrm{m}^{3}\right)\end{array}$ & 847 & 482 & 976 \\
\hline
\end{tabular}

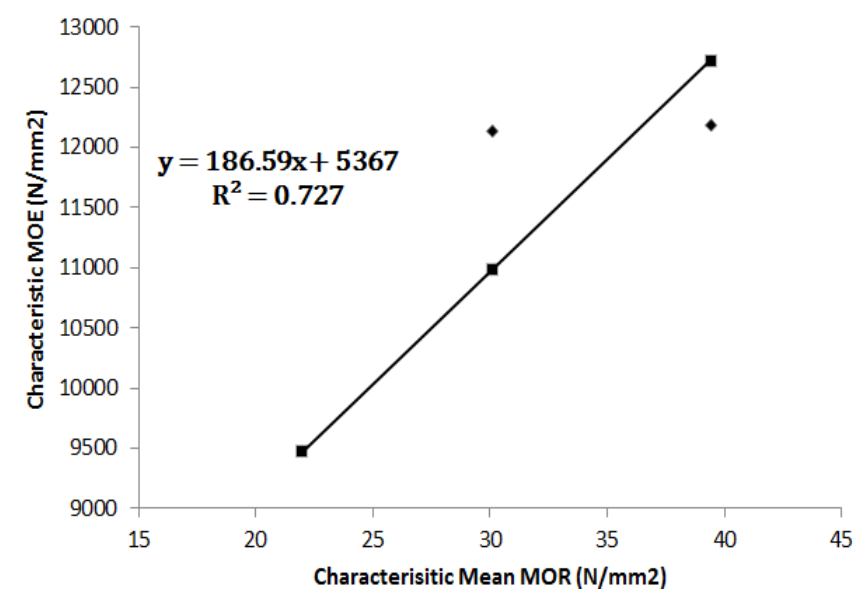

Figure 5: Modulus of Elasticity and Modulus of Rupture relations of the species.

Based on the same criteria, Ceiba pentandra and Pseudocedrela kotschyi timber species were assigned to strength classes $\mathrm{C} 16$ and D35 respectively.

The coefficient of determination $\left(\mathrm{r}^{2}\right)$ is $72.7 \%$ which implies a good correlation between the modulus of elasticity for the three timber species and their modulus of rupture as shown in Figure 5. For every 1 $\mathrm{N} / \mathrm{mm}^{2}$ increase in Modulus of Rupture, the Modulus of Elasticity increases by $186.59 \mathrm{~N} / \mathrm{mm}^{2}$.

Figure 6 shows a relationship curve between characteristic bending strength and characteristic density which would help to predict bending strength

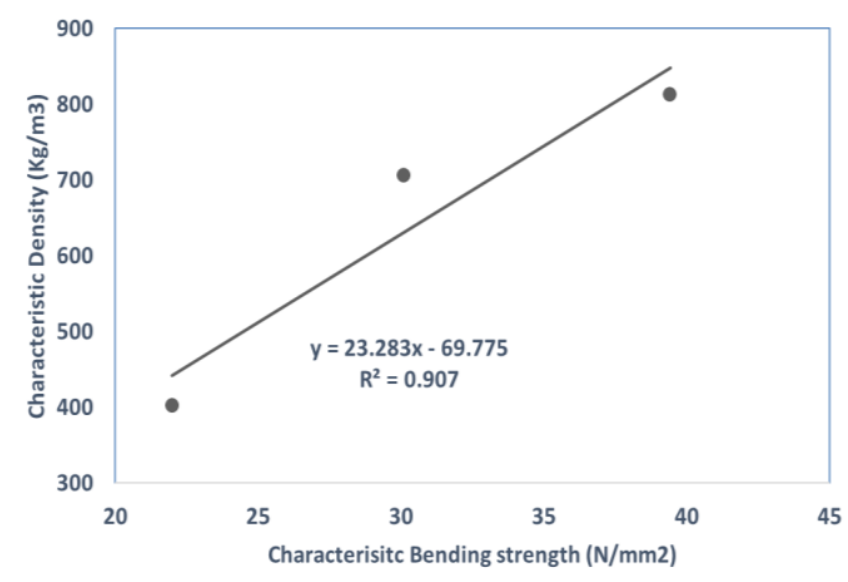

Figure 6: Relationship curve between characteristic bending strength and characteristic density

once the density is obtained. The coefficient of determination $\left(\mathrm{r}^{2}\right)$ is $90.7 \%$ which shows a good correlation between the two timber properties.

\section{LOAD/ DEFLECTION CURVE FOR THE NIGERIAN TIMBER SPECIE}

Figure 7, Figure 8 and Figure 9 shows a relation between the load and deflection for the potential timbers specie. A corresponding increase in load with increase in deflection was observed for all the timber species until a point of rupture. 


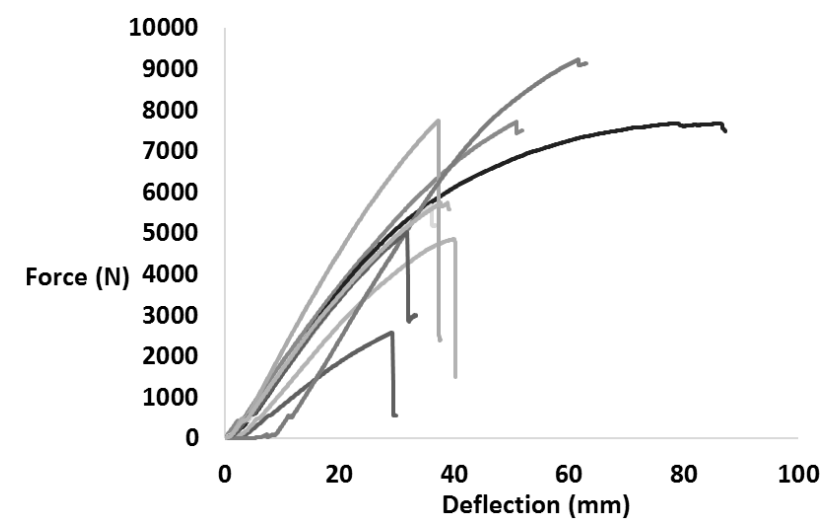

Figure 7: Load-Deflection curve for Pseudocedrela

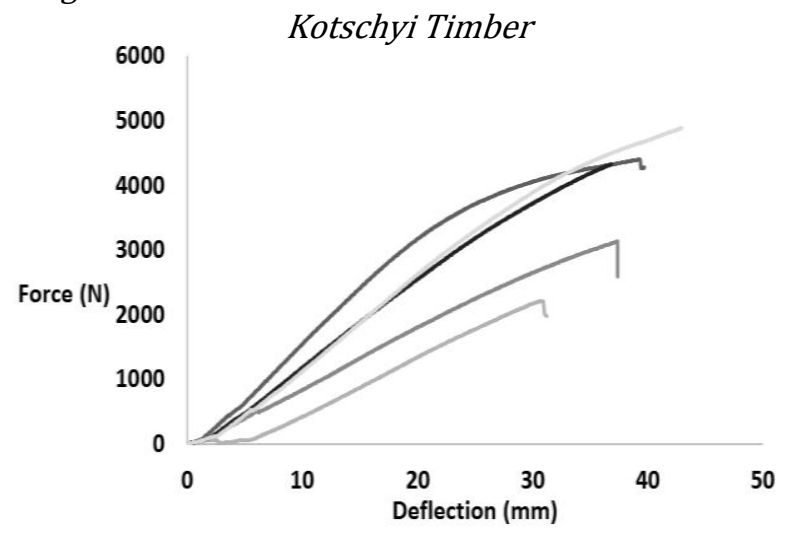

Figure 8: Load-Deflection curve for Ceiba Pentandra Timber

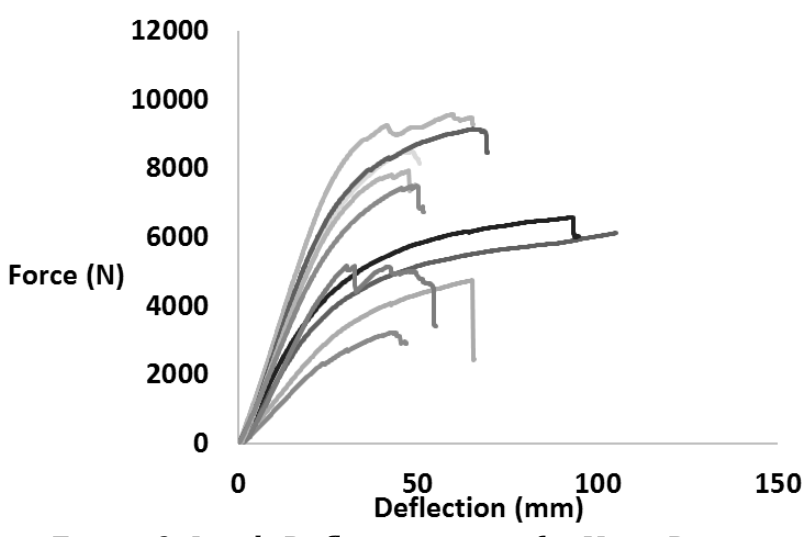

Figure 9: Load-Deflection curve for Vitex Doniana Timber

\section{CONCLUSION}

Ceiba pentandra is a coniferous specie (softwood) because its characteristic density fall within the softwood density range of $290-460 \mathrm{~kg} / \mathrm{m}^{3}$ as classified in EN338 [7]. Vitex doniana and Pseudocedrela kotschyi are deciduous species (hardwood) because their characteristic densities of $706 \mathrm{~kg} / \mathrm{m}^{3}$ and 813 $\mathrm{kg} / \mathrm{m}^{3}$ fell within the hardwood density range of 475 $900 \mathrm{~kg} / \mathrm{m}^{3}$ as classified in EN338[7]. Furthermore, the timbers were assigned to appropriate strength classes based on the European structural timber strength classification systems in [7]. Ceiba pentandra, Vitex doniana and Pseudocedrela kotschyi were assigned to strength class C16, D30 and D35 respectively. From the results, Ceiba pentandra is recommended for lowbearing structures and household furnitures while Vitex doniana and Pseudocedrela kotschyi can be used for load bearing structures.

Lack of adequate information (mechanical properties) on the lesser-used species in Nigeria can lead to the over-exploitation of the few commercial species such as Ayin, Mahogany, Obeche and Teak whose properties are well known. Therefore more research should be channeled on classification of less-used timber specie. The authors conclude that the work would serve as a revision to the Nigerian timber design code so as to meet up with international standards.

\section{REFERENCES}

[1] Saravanan, V., Parthiban, K., Thirunirai, R., Kumar, P., Vennila, S. and Umesh Kanna, S. "Comparative study of Wood Physical and Mechanical properties of Melia dubia with Tectona grandis at different Age Gradation", Research Journal of Recent Sciences, Vol.3, pp 256-263, 2014.

[2] Owoeye, P. and Abejide, 0. "Stochastic assessment of Nigerian wood for Bridge decks", Nigerian Journal of Technology, Vol.34, Number 2, pp 272279, 2015.

[3] Adebara, S., Hassan, H., Shittu, M. and Anifowose, M. "Quality and Utilization of Timber Species for Building Construction in Minna, Nigeria", The International Journal Of Engineering And Science, Vol. 3, Number 5, pp 46-50, 2014.

[4] Ezeagu, C., Eromosele, A., Okoro, H., Chukwujekwu, U. and Emetomo, T. "Flexural Strength of solid and glue-laminated timber beams", American Journal of Engineering Science and Technology Research. Vol. 3, Number 1, pp 1-14, 2015.

[5] Aguwa, J. I. "Reliability Assessment of the Nigerian Apa (Afzelia Bipindensis) Timber Bridge beam subjected to Bending and deflection under the Ultimate Limit state of Loading", International Journal of Engineering and Technology Vol. 2, Number 6, pp 1076-1088, 2012.

[6] Appiah-Kubi, E., Kankam, C., and Adom-Asamoah, $\mathrm{M}$. "Bending and modulus of elasticity properties of 10 lesser-used timber species in Ghana", Ghana Journal of Forestry, Vol. 28, Number 1, pp 15-28. , 2012.

[7] EN 338. Structural timber - Strength Classes. European Committee for Standardization. Austrian 
Standards Institute Heinestrase 38, 1020 Wien, 2009.

[8] EN 13153-1. Moisture Content of a Piece of Sawn Timber-Part 1.Determination by Oven Dry Method .Comite Europeen de Normalisation, Brussels, Belgium, 2002.

[9] EN 408. European Standard: Timber structures Structural Timber - Determination of some physical and mechanical properties. Comite Europeen de Normalisation, Brussels, Belgium, 2004.

[10] Abubakar, I., and Nabade, A. "Physical and Mechanical Properties of Some Common Nigerian Timber Species Based on Limit State Design Approach", Study of Civil Engineering and Architecture, Vol. 2, Number 4, pp 90-97, 2013.

[11] EN 384. Timber Structures; Structural timber Determination of Characteristic Values of Mechanical Properties and Density, ComiteEuropeen de Normalisation, Brussels, Belgium, 2004.

[12] Antwi, K., Effah, B., Adu, G., and Adu, S. "Strength and some Physical Properties of Allanblackia Parviflora for Furniture Production in Ghana", International Journal of Science and Technology, Vol. 4, No. 1, pp. 1 - 8. 2014.
[13] Zziwa, A., Kambugu, R., Kizito, S., Mugisha, A., Sseremba, 0. and Syofuna, A. "Evaluation of Basic Strength Indicators of Mangifera Indica Timber to ascertain its Suitability For Furniture Construction", International Journal of Research in Engineering \& Advanced Technology, Vol. 4, Number 1, 2016.

[14] Abubakar, I. and Nabade, A. "Bending Strength Classification of Some Common Nigerian Timber Species", Jordan Journal of Civil Engineering, Vol. 8, Number 2, pp 113-119, 2014.

[15] Ajuwa, J.I. "The Nigerian Timber Structures", Ahmadu Bello University Press limited Samaru, Zaria, Nigeria, 2016.

[16] Kaura, J., Abubakar, L., Aliyu, I. and Hassan, U. "EN 338 Strength grade and uncertainty models of material properties for Nigerian Grown Terminalia superba (White Afara) timber specie", Nigerian Journal of Technology,Vol.34, Number 1, pp 21-27, 2015.

[17] Mohammed, J. "Relaibility based analysis and calibration of Eurocode 5 Design criteria for solid timber portal frame", PhD. Thesis, Department of Civil Engineering, Faculty of Engineering, Ahmadu Bello University, Zaria, 2014. 